\title{
Penerapan Strategi Multiple Intelligences pada Mata Pelajaran Pendidikan Agama Islam (Studi Kasus di SMP Negeri 3 Sungailiat)
}

\author{
Habibah \\ Pascasarjana \\ IAIN Syaikh Badurrahman Siddik Bangka Belitung \\ habibahspdi2559@yahoo.com
}

\begin{abstract}
The success of the students are determined by the teacher who can guide them in learning and mastering the certain competencies. The psychological aspects show the fact that students generally have defferent levels of development, which also dmand different materi, everyone has deifferent ablities and talents. This study aims to find out how the aplication of Multiple Intelligences Strategies work in the sbujects of islamic education in SMP Negeri 3 Sungailiat and its influence on student learning education. The result of the study showed that by applying the Multiple Intelligences strategy in the subjects of islamic education proved that the level of student activity had been increased. There are also an obstacles in aplication of learning strategies multiple intellegencesa : learning prepartion, implementation of learning and assessment. Therefore, lectures sued to more creative in improving intellignces of students.
\end{abstract}

Keywords : Multiple Intelligences, Learning Strategies, Moral Creed.

\section{A. PENDAHULUAN}

Proses belajar mengajar merupakan kegiatan yang sangat kompleks yang berperan penting dalam mengembangkan sumber daya manusia oleh sebab itu kegiatan tersebut dapat berlangsung secara efektif dan efisien jika sehingga terbentuk komunikasi antara pendidik, peserta didik, dan orang tua baik di Sekolah, Rumah, maupun lingkungan masyarakat tertentu. Kesuksesan peserta didik sangatlah ditentukan oleh kerjasama orang tua dan guru yang dapat membimbingnya dalam belajar serta menguasai kompetensi tertentu.

Pendidikan adalah usaha yang telah terencana dalam mewujudkan suasana belajar dan proses pembelajaran agar peserta didik secara aktif mengembangkan potensi dirinya 
untuk memiliki kekuatan spiritual keagamaan, pengendalian diri, kepribadian, kecerdasan, akhlak mulia, serta keterampilan yang diperlukan dirinya dan masyarakat. ${ }^{1}$

Pendidikan agama Islam merupakan salah satu bidang studi di lembaga pendidikan umum yang bertujuan membantu anak didik untuk memperoleh kehidupan yang bermakna, sehingga mereka mendapatkan kebahagiaan hidup di dunia dan di akhirat, baik secara individu maupun kelompok. Dalam Pendidikan agama Islam anak didik akan mendapatkan pengajaran tentang tata cara beribadah untuk mendekatkan diri dengan Tuhan dan tata cara berhubungan dengan sesama manusia, saling menghormati, menghargai dan menyayangi. ${ }^{2}$ Pelayanan pendidikan bagi setiap anak yang memiliki kebutuhan khusus tentu akan berbeda-beda, tergantung kekurangan apa yang dialami oleh anak tersebut sehingga pelayanannya pun dapat sampai kepada anak tersebut dengan tepat.

Bagi anak-anak tingkat sekolah menengah pertama adalah perkembangan lebih baik untuk penanaman nilai-nilai agama Islam yang sudah sejak dini diperlukan untuk bekal dalam kehidupan sehari-hari. Menurut Zakiah Darajat, ia mendefiniskan bahwa nilai adalah suatu perangkat keyakinan atau perasaan yang diyakini sebagai suatu identitas yang memberikan corak yang khusus kepada pola pemikiran dan perasaan, keterikatan maupun perilaku. $^{3}$

Dalam rangka mencapai keberhasilan pembentukan kepribadian anak agar mampu terwarnai dengan nilai-nilai agama, maka perlu didukung oleh unsur keteladanan dan pola interaksi yang efektif dari orang tua dan guru. Guru adalah unsur manusiawi dalam pendidikan.Untuk menjadi seorang guru diperlukan syarat-syarat khusus, sebagai guru yang profesional harus menguasai betul seluk-beluk pendidikan dan pengajaran dengan berbagai ilmu pengetahuan lainnya yang perlu dibina dan dikembangkan melalui masa pendidikan tertentu. ${ }^{4}$

Peran guru dalam menanamkan nilai-nilai agama pada siswa-siswi sangatlah urgen. Tercapainya tujuan proses belajar mengajar dalam kegiatan pendidikan dan pengajaran, memerlukan usaha terciptanya interaksi yang baik antara guru yang mengajar

\footnotetext{
${ }^{1}$ Hasbullah, Dasar-dasar Ilmu Pendidikan Revisi Cet. 12, (Jakarta: Rajawali Pers 2015), hlm. 308.

${ }^{2}$ Ahmad Tafsir, Ilmu Pendidikan Dalam Persfektif Islam, (Bandung: Remaja Rosda Karya, 2001), hlm. 46.

${ }^{3}$ Zakiah Darajat, Dasar-Dasar Agama Islam, (Jakarta: Bulan Bintang, 2004), hlm. 260.

4 Syaiful Bahri Djamarah, Guru Dan Anak Didik Dalam Interaksi Edukatif, (Jakarta: Rineka Cipta, 2000), hlm. 1.
} 
dan peserta didik yang belajar. ${ }^{5}$ Dalam proses pembelajaran dalam penanaman nilai agama pada siswa sekolah menengah pertama sikap sabar sangat diperlukan oleh guru, karena akan banyak masalah yang muncul dalam pembelajaran yang akan dihadapi, seperti hambatan mental yang mereka miliki. Sebagai contoh, beberapa problem yang terjadi berdasarkan dari hasil observasi peneliti sebagai salah satu guru Pendidikan Agama Islam Di SMP Negeri 3 Sungailiat bahwa diantaranya yaitu pada saat pembelajaran berlangsung guru harus bekerja keras, di mana guru dituntut untuk sabar, kreatif, dan pintar memodifikasi berbagai strategi-strategi agar anak mudah mencerna materi yang di sampaikan.

Kelemahan sekolah dan guru adalah bahwa mereka kaku dalam mengajarkan suatu mata pelajaran dan keterampilan guru dalam memberikan materi dengan cara yang biasanya tidak peduli terhadap variasi kecerdasan siswa yakni hanya melalui gabungan antara ceramah, penggunaan papan tulis, buku pelajaran, dan lembar latihan dan jika anakanak tidak memahaminya itu adalah masalah mereka bukan guru, artinya para guru sebenarnya sudah menerapkan strategi Multiple Intelligences, namun mereka belum terlalu fokus khususnya terhadap kecerdasan siswa yang variatif. Sehingga dalam menerapkan strategi multiple Intelligences di kelas, guru harus bisa memahami dan mengerti kemampuan siswanya yang berbeda-beda, dan merubah pandangannya terhadap anak yang kurang dalam belajar, karena masing-masing anak memiliki kecerdasan yang berbeda untuk menunjukkan potensi diri yang mereka miliki.

Di SMP Negeri 3 Sungailiat telah melaksanakan strategi multiple intelligences salah satunya dengan membuat RPP yang berbeda bagi peserta didik, di mana dalam satu kelas terdapat peserta didik yang memiliki kemampuan yang berbeda-beda dan juga terdapat anak yang berkebutuhan khusus yang tidak mungkin untuk disamakan dalam pembelajaran.Jika dilihat dari perkembangan tentang strategi guru PAI dalam menerapkan strategi multiple intelligences, guru pendidikan agama Islam di SMP Negeri 3 Sungailiat ini sudah mulai menerapkannya akan tetapi masih belum fokus dan mendalam, karena ketika menerapkan strategi multiple intelligences guru masih belum secara total dalam merancang strategi belajar, menggunakan strategi mengajar yang tepat, serta penggunaan media belajar yang tepat untuk merangsang kecerdasan setiap anak agar dapat hlm. 5 .

\footnotetext{
${ }^{5}$ Moh Uzer Usman, Menjadi Guru Profesional, (Bandung: Remaja Rosdakarya, 1992),
} 
meningkatkan kualitas belajar. Sehingga diharapkan semua anak dapat antusias dalam menerima materi pelajaran, dan kegiatan belajar mengajarpun dapat menjadi lebih baik.

Berdasarkan urian di atas, dapat disimpulkan bahwa pemasalahan yang dialami guru sekolah menengah pertama adalah (1) dalam proses mengajar guru dituntut sabar, kreatif dan pintar memodifikasi berbagai strategi agar anak mudah mencerna materi yang disampaikan, (2) dalam proses mengajar guru dianggap kaku dalam menyampaikan materi pembelajaran, (3) penerapan strategi multiple intelligences belum maksimal dikarenakan guru yang belum memahami dan mengerti kemampuan siswanya yang berbeda-beda, (4) strategi multiple intelligences guru masih belum secara total dalam merancang strategi belajar, menggunakan strategi mengajar yang tepat, serta penggunaan media belajar yang tepat untuk merangsang kecerdasan setiap anak agar dapat meningkatkan kualitas belajar.

\section{B. KAJIAN TEORI}

1. Konsep Multiple Intelligences

Multiple Intelligences terdiri dari dua kata "Multiple" dan "Intelligences"yang dalam bahasa Inggris Multiple bermakna berbagai jenis, Intelligence bermakna kecerdasan. ${ }^{6}$ Sedangkan dalam Ensiklopedi Nasional Indonesia disebutkan bahwa kata Inteligensi merupakan kata yang berasaldari bahsa latin yaitu Intelegere, yang berarti mengerti, yakni kemampuan dasar, kapabilitas, dan kapasitas yang bersifat umum yang dimiliki seseorang. ${ }^{7}$

Menurut Stern"Intelegensi" adalah daya untuk menyesuaikan diri secara mudah dengan keadaan baru yang menggunakan bahan-bahan pikiran yang ada menurut tujuannya. ${ }^{8}$ Dalam Kamus lengkap Psikologi disebutkan istilah Multi Modal Theory OfIntelligensi, teori ini menyatakan Intelligensi itu tersusun atas sejumlah besar kemampuan khusus dan tidak merupakan kemampuan umum yang tunggal. ${ }^{9}$

Dari beberapa definisi tersebut dapat disimpulkan bahwa Multiple Intelligences adalah sejumlah kecerdasan yang dimiliki manusia yang dapat dikembangkan secara terus

\footnotetext{
${ }^{6}$ Munif Chatib, Sekolahnya Manusia, (Bandung: Kaifa, 2009), hlm. 71.

${ }^{7}$ Ensiklopedi Nasional Indonesia, (Jakarta: PT. Cipta Adi Pustaka, 1988), hlm.189.

${ }^{8}$ Soegarda Poerbakawatja Harahap, EnsiklopediPendidikan, (Jakarta: PT.Gunung Agung, 1982), hlm.148.

${ }^{9}$ C.P. Chaplin, Kamus Lengkap Psikologi, (Jakarta: PT. Raja Grafindo Persada, 1993), hlm.31216.
} 
| HABIBAH | Penerapan Strategi Multiple Intelligences....

menerus sehingga dapat membantu proses pembelajaran menjadi lebih mudah dan menyenangkan.

2. Penerapan Strategi Multiple Intelligences

a. Prosedur Penerapan Multiple Intelligences

Strategi multiple intelligences adalah gaya mengajar guru disesuaikan dengan gaya belajar siswanya yang berarti adalah kemampuan seorang siswa menangkap dan memahami informasi yang diberikan oleh guru atau siapapun dengan pola-pola yang khas. Gaya belajar ini jumlahnya banyak dan tidak menjadi hal yang permanen artinya dapat berubah-ubah, tergantung stimulus dari lingkungan yang mempengaruhinya. Oleh karena itu guru dengan mudah menentukan dan memilih metode apa yang ingin disajikan kepada siswa-siswanya. ${ }^{10}$

Strategi-Strategi yang dapat digunakan dalam Multiple intelligences sesuai dengankecerdasan sebagai berikut: ${ }^{11}$

1) Strategi pengajaran untuk kecerdasan linguistik dan logis matematis; yakni dengan bercerita, saling memberikan pandangan atau ide, Merekam dengan tape recorder, Menulis jurnal dan Publikasi.

2) Strategi pengajaran untuk kacardasan logis matematis; Kalkulasi dan kuantifikasi, Klasifikasi dan kategori, Pertanyaan sokratis, Heuristic dan Penalaran ilmiah.

3) Strategi pengajaran untuk kecerdasan spasial; Visualisasi, yakni bisa dengan Penggunaan warna, Metafora gambar, Sketsa gagasan dan Simbol grafis.

4) Strategi pengajaran untuk kecerdasan kinestetis; Respon tubuh, Teater kelas, Konsep kinestesis (pantonim), Hands On Thinking dan Peta tubuh.

5) Strategi pengajaran untuk kecerdasan interpersonal; Berbagi rasa dengan teman sekelas, Formasi patung dari orang, Kerja kelompok, Board games dan Simulasi.

6) Strategi pengajaran untuk kecerdasan intrapersonal; Sesi refleksi satu menit, Momentum mengekspresikan perasaan, Sesi perumusan tujuan, Waktu memilihdanHubungan mata pelajaran dengan pengalaman pribadi.

7) Strategi pengajaran untuk kecerdasan musik; Irama, lagu, rap, dan senandung, Diskografi, Musik super memori, Konsep musical dan Musik suasana.

\footnotetext{
${ }^{10}$ Munif Chatib, Gurunya Manusia, (Bandung :Kaifa, 2016), hlm. 141.

${ }^{11}$ Hamzah B. dan Masri Kuadrat, Mengelola Kecerdasan dalam Pembelajaran: Sebuah Konsep Pembelajaran Berbasis Kecerdasan, (Jakarta: Bumi Aksara, 2009), hlm.129-156.
} 
8) Strategi pengajaran untuk kecerdasan naturalis; Jalan-jalan di tempat terbuka, Melihat keluar jendela dan Ekostudi.

\section{b. Problematika Penerapan Multiple Intelligences}

Pelaksanaan proses belajar yang menggunakan kerangka Multiple Intelligences tidaklah sesulit yang dibayangkan. Yang dibutuhkan hanyalah kreativitas dan kepekaan guru. sehingga setiap guru harus bisa berpikir secara terbuka yaitu keluar dari paradigma pengajaran tradisional, mau menerima perubahan, serta harus memiliki kepekaan untuk melihat setiap hal yang bisa digunakan di lingkungan sekitar dalam menunjang proses belajar. Untuk mengembangkan proses pengajaran dengan menggunakan Multiple Intelligences, sarana dan prasarana yang dibutuhkan sebenarnya telah tersedia di lingkungan sekitar. Hal tersebut berarti bahwa pendidikan tidak hanya bisa dilakukan di dalam kelas, tdak hanya menggunakan peralatan yang canggih. Akan tetapi siswa bisa diajak keluar kelas untuk mengamati setiap fenomena yang terjadi di dunia nyata.Sehingga siswa tidak hanyadijejali oleh teori semata. Mereka dihadapkan dengan kenyataan bahwa teoriyang mereka terima memang dapat ditemui di dalam kehidupan nyata dandapat mereka alami sendiri sehingga mereka memiliki kesan yang mendalam.

Vernon A. Magnesen ${ }^{12}$ menyebutkan bahwa kita belajar $10 \%$ dari apa yang kita baca, 20\% dari apa yang kita dengar, 30\% dari apa yang kita lihat, 50\% dari apa yang kita lihat dan dengar, 70\% dari apa yang kita katakan, 90\% dari apa yang kita katakan dan lakukan. Artinya seseorang bisa menyerap pelajaran dengan maksimal pada saat dia melakukan atau mempraktekkan materi yang diterimanya. Dalam menerapkan berbagai metode pengajaran yang berkembang akhir-akhir ini tidaklah selalu memerlukan suatu peralatan yangc anggih yang dapat menunjang proses pembelajaran. Akan tetapi Di dalam menerapkan Multiple Intelligences di dalam proses pengajaran dapat dilakukan melalui beberapa cara, di antaranya dengan menggunakan musik untuk mengembangkan Musical Intelligence, belajar kelompok untuk mengembangkan Interpersonal Intelligence, dan lainlain. Penerapan Multiple Intelligences didalam proses belajar mengajar semestinya tidak hanya menunggu perintah dari atasan.

Dalam Penerapan Multiple Intelligences Ada beberapa keuntungan yang dapat diperoleh diantaranya adalah pertama, Kita dapat menggunakan kerangka Multiple

${ }^{12}$ DePorter, Quantum Teaching; Mempraktikkan Quantum Learning Di Ruang-Ruang Kelas, (Bandung:PT. Mizan Pustaka, 2000), hlm. 67. 
Intelligences dalam melaksanakan proses pengajaran secara luas misalnya dengan melakukan aktivitas seperti menggambar, menciptakan lagu, mendengarkan musik, melihatsuatu pertunjukan. Kedua, Dengan menggunakan Multiple Intelligences berarti telah menyediakan kesempatan bagi siswa untuk belajar sesuai dengan kebutuhan, minat,dan talentanya. Ketiga, Peran serta orang tua dan masyarakat akan semakin meningkat di dalam mendukung proses belajar mengajar. Hal ini bisa terjadi karena setiap aktivitas siswa di dalam proses belajar akan melibatkan anggota masyarakat. Keempat, Siswa akan mampu menunjukkan dan 'berbagi' tentang kelebihan yangdimilikinya. Kelima,Pada saat Anda 'mengajar untuk memahami', siswa akan mendapatkan pengalaman belajar yang positif dan meningkatkan kemampuan untuk mencari solusi dalam memecahkan persoalan yang dihadapinya.

3. Konsep Pendidikan Agama Islam

a. Pengertian Pendidikan Agama Islam

Dalam konteks keislaman, pendidikan Islam lebih dikenal dengan istilah $A l$ Tarbiyat. Seperti uangkapan Athiyah al- Abrasyi yang dikutip oleh Ramayulis, ia menyebutkan bahwa Al-Tarbiyahmerupakan suatuprosesyang di dalamnya merupakan keseluruhan dari kegiatan pendidikan yakni upaya untuk menyiapkan individu untuk menuju kehidupan yang lebih sempurna, memiliki etika, memiliki pola pikiryang sistematis, memiliki ketajaman intuisi, mengembangkankrativitas, memiliki toleransi pada orang lain, serta dapat berkompetisi dan memiliki berbagai keterampilan. ${ }^{13}$

Hasan Langgulung mendefinisikan pendidikan Islam sebagai "suatu proses dalam menyiapkan generasi muda dalam membentuk sebuah peranan, proses transfer pengetahuan dan nilai-nilai Islam yang dihubungkan dengan fungsi manusia supaya dapat beramal dalam kehidupan di dunia dan menuai hasilnya di akhirat. Dalam hal ini pendidikan Islam lebih menekankan pada proses pembentukan individu yang didasarkan pada ajaran Islam yang diwahyukan Allah SWT kepada Nabi Muhammad Saw. Tegasnya, senada dengan apa yang dikemukakan Ahmad D. Marimba, "pendidikan Islam adalah

\footnotetext{
${ }^{13}$ Muhammad Athiyah al Abrasyi, Al- Tarbiyah al Islamiyah, Cet. 3, (Dar al Fikr al Arabi, tt), hlm. 100 .
} 
bimbingan jasmani dan rohani menuju terbentuknya keperibadian utama menurut ukuranukuran Islam. ${ }^{14}$

Secara metodologis ilmu pendidikanIslam juga harus memenuhi metodologi ilmu pendidikan yang tidak menggunakan predikat Islam.karena ilmu pendidikan Islam sepenuhnya melibatkan nilai-nilai Islami dalam proses penyusunan desaign, intrumen, pembuahan analisis dan pembentukan kesimpulannya. Misalnya, demi kepentingan bangsa dan negara, pendidikan kesadaran berbangsa dan bernegara harus dilakukan. Sejarah pendidikan Islam ialah studi tentang pemikiran dan pelaksanaan pendidikan Islam baik masa lalu maupun dimasa sekarang.

b. Ruang Lingkup Pendidikan Agama Islam

Adapun unsur-unsur yang terlibat dalam pendidikan Islam sekaligus menjadi ruang lingkup pendidikan Islam adalah sebagai berikut ${ }^{15}$ :

1) Perbuatan mendidik

2) Peserta didik

3) Dasar dan tujuan pendidikan Islam

4) Pendidik

5) Materi pendidikan Islam

6) Metode pendidikan Islam

7) Evaluasi pendidikan Islam

8) Alat-alat pendidikan Islam

9) Lingkungan pendidikan Islam

c. Strategi Pembelajaran Pendidikan Agama Islam (PAI)

Strategi menurut Kemp adalah kegiatan dalam proses belajar mengajar yang harus dilaksanakan oleh pendidik dan peserta didik sehingga tujuan pembelajaran dapat dicapai secara efektif dan efisien. ${ }^{16}$ Artinya bahwa strategi merupakancara dan daya untuk menghadapi situasi dan kondiri agar memperoleh hasil yang diharapkan secara maksimal.

\footnotetext{
${ }^{14}$ Azyumardi Azra, Pendidikan Islam Tradisi dan Modernisasi di Tengah Tantangan Milenium Ill, (Jakarta: Prenada Madia Group, 2012), hlm. 5.

${ }^{15}$ Akh.Muzakki \& Kholilah, Ilmu Pendidikan Agama Islam, Cet. 5, ( Surabaya: Mesmedia Buana Pustaka, 2011), hlm. 19.

${ }^{16}$ Abdul Majid, Belajar dan Pembelajaran Pendidikan Agama Islam, (Bandung: PT. Remaja Rosdakarya, 2012), hlm. 130.
} 
Ada beberapa factor dalam menentukan strategi pembelajaran, yakni sebagai berikut: ${ }^{17}$

1) Menerapkan perubahan yang diharapkan; perubahan dalam penyusunan strategi pembelajaran dapat berupa perubahan pengetahuan, wawasan, keterampilan dan sikap yang harus ditetapkan secara spesifik, terencana dan terarah.

2) Menerapkan pendekatan; pendekatan merupakan sebuah kerangka analisa yang dapat digunakan dalam memahami sebuah persoalan. Maka, dalam hal ini dilihat bagaimana cara pendidikan menyelesaikan suatu persoalan, konsep, serta teori yang akan digunakan pendidik dalam memecahkan suatu persoalan.

3) Menerapkan metode; Penggunaan metode haruslah menyesuaikan dengan tujuan yang ingin dicapai, memperhatikan bahan pelajaran yang akan disampaikan, kondisi peserta didik, lingkungan dan kemampuan pendidik itu sendiri.

Metode yang digunakan dalam pembelajaran PAI tidak akan berarti jika tidak dilaksanakan dalam praktek pendidikan. Pelaksanaan metodologi pembelajaran PAI itu diantaranya memilih metode mangajar yang efektif dan efisian. Dalam al-Qur'an banyak metode yang bisa diterapkan untuk menyampaikan kalam-kalam Allah kepada manusia, seperti metode cerita, diskusi, tanya jawab (dialog), metode perumpamaan (metafora), metode hukuman dan ganjaran. ${ }^{18}$

Selain metode yang terdapat dalam Al-Qur'an, Ramayulis menyebutkan beberapa metode yang dapat kita gunakan dalam pembelajaran Pendidikan agama Islam, diantaranya : metode ceramah, diskusi, tanya jawab, demontrasi, karyawisata, penugasan, pemecahan masalah, simulasi, eksperimen, penemuan, sosio drama, kerja kelompok dan lain-lain. ${ }^{19}$ Metode-metode tersebut telah banyak dipraktekkan oleh GPAI disekolah terutama metode ceramah dan tanya jawab. Ada beberapa komponen yang harus ada dalam proses pembelajaran, yaitu: ${ }^{20}$

1) Peserta Didik

\footnotetext{
${ }^{17}$ Remiswal dan Rezki Amelia, Format Pengembangan Strategi..., Ibid., hlm. 32.

${ }^{18}$ Abdurrahman Saleh Abdullah, Teori-teori Pendidikan berdasarkan Al-Qur'an, cet. kedua, (Jakarta: Rineka Cipta, 1994), hlm. 197-231.

${ }^{19}$ Ramayulis, Metodologi Pengajaran Agama Islam, cet ketiga, (Jakarta: Kalam Mulia, 2001), hlm. 108-109.

${ }^{20}$ Remiswal dan Rezki Amelia, Format Pengembangan Strategi..., Ibid., hlm. 22-23.
} 
Pada hakikatnya proses pembelajaran merupakan upaya yang dilakukan untuk mengajarkan peserta didik agar dapat mencapai tujuan yang telah ditentukan. Dengan demikian, maka peserta didik haruslah dijadikan pusat dari segala kegiatan dalam proses mengembangkan perencanaan dan mendesain pembelajaran. Artinya keputusan yang diambil dalam perencanaan dan desain pembelajaran disesuaikan dengan kondisi peserta didik yang bersangkutan, diantaranya sesuai dengan kemampuan dasar, minat dan bakat, motivasi belajar dan gaya belajar siswa itu sendiri.

2) Tujuan

Setelah komponen peserta didik, komponen terpenting dalam pembelajaran adalah komponen tujuan pembelajaran. Komponen ini diibaratkan jantung pada sistem tubuh manusia.

3) Isi (Materi)

Materi pelajaran haruslah terdiri dari fakta-fakta, generalisasi, konsep, hukum atau aturan dan sebagainya, di mana materi tersebut tergantung dalam mata pelajaran yang diajarkan.

4) Metode

Metode adalah suatu cara yang dipergunakan untuk mencapai tujuan yang ingin ditetapkan. Keberhasilan tujuan tersebut sangat ditentukan oleh komponen ini. Bagaimanapun lengkap dan jelasnya komponen lain, tanpa dapat penerapan dengan strategi yang tepat, maka komponen tersebut tidak akan memiliki makna dalam proses pencapaian tujuan.

5) Alat

Alat adalah segala sesuatu atau sarana yang dapat digunakan dalam rangka mencapai tujuan pembelajaran.

6) Media

Media pengajaran merupakan segala sesuatu yang dapat digunakan untuk menyalurkan pesan atau isi pelajaran, merangsang pikiran, perasaan, perhatian dan kemampuan siswa, sehingga dapat mendorong proses belajar mengajar.

7) Evaluasi 
Evaluasi merupakan komponen pembelajaran yang dilaksanakan diakhir proses pembelajaran yang bertujuan untuk meneliti atau menganalisa hasil dalam proses belajar siswa dan untuk mengetahui kesulitan yang melekat pada proses belajar.

\section{METODE PENELITIAN}

Jenis Penelitian yang digunakan adalah penelitian lapangan yaitu penelitian yang dilakukan secara intensif, terperinci dan mendalam terhadap suatu objek tertentu dengan mempelajarinya sebagai suatu kasus. Pendekatan penelitian yang digunakan adalah menggunakan pendekatan kualitatif. Lokasi Penelitian dilakukan di SMP Negeri 3 Sungailiat yang beralamat Jalan Raya Belinyu Kelurahan Sinar Jaya Jelutung Kecamatan Sungailiat Kabupaten Bangka. Teknik yang digunakan dalam pengumpulan data adalah dengan melakukan Observasi, Wawancara, dan Dokumentasi ke SMP Negeri 3 Sungailiat. Adapun Proses Analisis Data dilakukan dengan cara Reduksi Data kemudian Display data dan tahap terakhir Verifikasi atau penarikan kesimpulan.

\section{PEMBAHASAN DAN DISKUSI HASIL PENELITIAN}

1. Penerapan Pembelajaran Dengan Menggunakan Strategi Multiple Intelligences Pada Siswa Kelas IX di SMP Negeri 3 Sungailiat

Penelitian ini dilaksanakan fokus pada guru PAI dan siswa kelas IX (Sembilan) di SMP Negeri 3 Sungailiat. Pada penelitian ini peneliti hanya fokus pada kelas IX (Sembilan) yang memiliki siswa berjumlah 269 Orang dengan jumlah siswa yang beragama Islam sebanyak 222 Orang, yang diampu oleh satu orang Guru Pendidikan Agama Islam. Dalam proses kegiatan belajar mengajar di kelas, SMP Negeri 3 Sungailiat memberlakukan 6 hari untuk jam kondusif belajar, yakni pada hari Senin sampai dengan hari Sabtu. Kegiatan tersebut dilakukan mulai pukul 07.15 sampai dengan pukul 12.45 wib. Sebelum pembelajaran di kelas dimulai siswa muslim terlebih dahulu dibiasakan untuk berdoa dan membaca Al-Quran.

a. Persiapan Pembelajaran dengan menggunakan strategi multiple intelligences

Dalam pembelajaran dengan menerapkan multiple intelligences sangat diperlukan persiapan yang matang. Karena hal tersebut akan berdampak pada berhasil atau tidaknya pembelajaran yang dilakukan oleh guru. Secara umum, ada dua tahap yang dilakukan SMP Negeri 3 Sungailiat dalam mempersiapkan pembelajaran dengan menggunakan strategi multiple intelligences yakni:

1) Mengenali Kecerdasan Siswa 
Menurut Umar Hadi ${ }^{21}$, SMP Negeri 3 Sungailiat dalam mengenali kecerdasan masing-masing siswa adalah dengan melaksanakan seleksi pada saat awal tahun ajaran baru atau setiap awal masuk kelas satu.Dalam mengenali kecerdasan masing-masing siswa SMP Negeri 3 Sungailiat masih menggunakan hasil dari UASBN dan belum menggunakan tes khusus seperti Tes Interest Multiple Intelligences yang bisa dilakukan oleh guru BK.

Berdasarkan yang telah diungkapkan oleh Umar Hadi di atas, bahwa SMP Negeri Sungailiat dalam mengenali kecerdasan siswa dapat dikatakan belum berhasil, dimana seharusnya dalam mengenali kecerdasan masing-masing siswa seperti yang diungkapkan oleh Paul Suparno dapat dilakukan melalui tes seperti Test InterestingMultiple Intelligences (TIMI), observasi dan dengan mengumpulkan data serta dokumen siswa.

2) Membuat Rencana Pembelajaran

Dalam pembelajaran menurut guru $\mathrm{PAI}^{22}$, persiapan yang dilakukan sebelum mengajar adalah menyusun Rencana Pembelajaran. Hal tersebut berdasarkan pernyataan kepala sekolah dan wakil kepala sekolah sebagai berikut:

Umar Hadi: "Diawal semester biasanya kita adakan rapat pembagian tugas, disitu ada penjelasan-penjelasan persiapan dalam rangka pembelajaran serta kegiatan. Jadi biase tu kalo guru ngajar tu kan harus punya RPP, di RPP nya tu mereka mencantumkan strategi mereka sendiri, macam mana mereka mengajar dikelas. Kemudian kalo dikelasnya disiapkan infokus dan lainnya. Karena kan kalo kite ngajar tu kan harus ade makai media yang otomatis nambah gairah anak-anak." ${ }^{23}$

3) Pelaksanaan Strategi Multiple Intelligences

a. Kegiatan apersepsi dan motivasi

Guru PAI dalam hal melaksanakan apersepsi dan motivasi dalam proses belajar mengajar dilakukan melalui 4 (empat) tahap, yakni: Alfa Zona, Warmer, Pre Teach dan Scene Setting.

Pertama Alfa Zona, berdasarkan hasil wawancara peneliti dengan guru PAI, menyatakan bahwa alfa zona berkaitan dengan otak, artinya di mana otak dalam kondisi

\footnotetext{
${ }^{21}$ Wawancara dengan Umar Hadi, Kepala SMP Negeri 3 Sungailiat,tanggal 18 Juli 2018 di Ruang Kepala Kepala SMP Negeri 3 Sungailiat.

${ }^{22}$ Wawancara dengan Yulnawati, Guru PAI SMP Negeri 3 Sungailiat,tanggal 18 Juli 2018 di Ruang Tunggu Tamu SMP Negeri 3 Sungailiat.

${ }^{23}$ Wawancara dengan Umar Hadi, Kepala SMP Negeri 3 Sungailiat,tanggal 18 Juli 2018 di Ruang Kepala Kepala SMP Negeri 3 Sungailiat.
} 
siap untuk menerima pembelajaran. Kegiatan alfa zona yang dilakukan guru PAI adalah olah piker dan daya refleksi sebelum belajar.

Kedua Warmer, Kegiatan yang dilakukan guru PAI dalam tahap ini adalah dengan mengulang materi yang telah disampaikan sebelumnya. kegiatan ini dilakukan pada awal pembelajaran yang dapat berupa pertanyaan atau penjelasan kembali pelajaran yang telah dipelajari. Kegiatan ini sering disebut dengan review dan feedback.

Ketiga Pre- Teach, berdasarkan hasil wawancara dengan guru PAI kegiatan Pre teach yang dilakukan adalah dengan menyampaikan kepada siswa kegiatan apa saja yang akan dilakukan dalam proses pembelajaran, pre teach tersebut dilakukan sebelum memulai mengajar. Hal ini hampir sama dengan yang diungkapkan oleh Munif Chatib bahwa kegiatan Pre Teach dapat dilakukan sebelum dilaksanakan kegiatan inti dalam pembelajaran.

Keempat scene setting, kegiatan ini penting bagi siswa, di mana siswa akan merasakan ada sebuah dorongan atau motivasi. Berdasarkan hasil observasi yang dilakukan peneliti, scene setting yang dilakukan oleh guru PAI adalah saat pembelajaran PAI dengan materi surat At-Tiin, guru mengajukan pertanyaan atau menyuruh siswa untuk membacakan surat At-Tiin yang diketahuinya, kemudian guru PAI memberikan apresiasi terhadap bacaan siswa tersebut.

b. Kegiatan Dalam Mengembangkan Kecerdasan Linguistik-verbal

Berdasarkan observasi peneliti, dalam mengembangkan kecerdasan linguisticverbal, kegiatan yang dilakukan guru PAI adalah dengan meminta siswa ceramah di depan kelas dan mengarang atau membuat sebuah cerita lalu membacanya di depan kelas.

Berdasarkan observasi peneliti, pada saat pembelajaran berlangsung peneliti melihat guru PAI meminta siswa untuk membuat cerita tentang pentingnya bersikap tasamuh, sejarah Islam, kisah perjuangan Nabi dan Rasul. Setelah itu siswa di minta satu per satu untuk membacakan hasil cerita yang telah dibuat di depan kelas. Pada saat itu salah satu siswa yang merupakan siswa inklusi tidak membuat cerita, namun guru PAI dapat membujuk siswa tersebut untuk bercerita di depan kelas dengan cerita bebas, meskipun cerita itu tidak dapat dipahami dan tidak selesai.

Kegiatan dalam mengembangkan kecerdasan linguistik-verbal yang juga dilakukan guru PAI adalah meminta siswa presentasi di depan kelas, siswa di minta untuk menceritakan kembali serta menyebutkan hikmah dari cerita yang pernah dibaca. 
Hal tersebut di atas sesuai dengan yang dikatakan oleh Thomas R. Hoer bahwa untuk mengembangkan kecerdasan linguistik yang dapat dilakukan guru adalah dengan mendorong menggunakan kata-kata yang lazim, melibatkan siswa dalam diskusi dan presentasi lisan.Pengembangan Kecerdasan Linguistik-verbal dapat juga diketahui dan diterapkan oleh guru terhadap siswa pada saat belajar misalnya pada saat praktek sholat.

c. Kegiatan Dalam Mengembangkan Kecerdasan Matematis-logis

Berdasarkan wawancara dengan guru PAI bahwa guru menyatakan untuk mengembangkan kecerdasan matematis-logis ini banyak dilakukan diluar jam pelajaran yang biasanya siswa disuruh mencari solusi untuk menyelesaikan masalah yang dihadapi siswa itu sendiri.

Kegiatan untuk mengembangkan kecerdasan matematis-logis banyak dilakukan diluar jam pelajaran, dalam hal ini siswa dibagi menjadi bebarapa kelompok, kemudian setiap kelompok ditentukan satu orang sebagai ketua kelompok sekaligus sebagai juru bicara. Setiap keompok diberikan permasalahan yang berbeda untuk didiskusikan masingmasing kelompok. Hasil diskusi tersebut di demonstrasikan, kemudian kelompok lain diberikan kesempatan untuk memberikan tanggapan. Berkaitan dengan mengembangkan kecerdasan matematis logis, pelajaran juga dilakukan dikelas seperti pada saat mempelajari materi tentang zakat, guru meminta siswa untuk simulasi cara perhitungan zakat.

d. Kegiatan Dalam Mengembangkan Kecerdasan Visual-spasial

Kegiatan yang dilakukan guru PAI untuk mengembangkan kecerdasan ini, sebagaimana disampaikan oleh guru PAI dalam wawancara adalah dengan mengajak siswa menonton film atau video, hal tersebut berdasarkan observasi, peneliti melihat siswa menonton film tentang hari kiamat kemudian setelah selesai menonton, siswa di minta untuk menceritakan kembali film tersebut.

Hal tersebut sesuai dengan yang disampaikan oleh Thomas Amstrong bahwa belajar dengan visual-spasial merupakancara terbaik untuk memberikan motivasi kepada anak yakni melalui media seperti film, video, slide, diagram, peta, grafik, serta memberikan kesempatan untuk menggambar dan melukis. Berdasarkan hasil observasi peneliti bahwa siswa diajak menonton film tentang hari kiamat kemudian setelah selesai menonton, siswa di minta untuk menceritakan kembali film tersebut sehingga siswa dapat mengambil hikmah di dalamnya.

e. Kegiatan Dalam Mengembangkan Kecerdasan Kinestetik 
Kegiatan yang dilakukan Guru PAI dalam mengembangkan kecerdasan kinestetik pada siswa, berdasarkan observasi peneliti adalah membiarkan siswa mengekspresikan atau melakukan kegiatan yang disukai siswanya misalnya menabuh meja, menggoyanggoyangkan badannya. Dan pada saat jam pelajaran akan selesai guru PAI dengan sengaja memberikan waktu untuk siswanya melakukan apa yang disukai. Hal ini juga di ungkapkan oleh guru PAI dalam wawancara sebagai berikut:
Peneliti : “apa saja kegiatan yang dilakukan dalam mengembangkan kecerdasan kinestetik bagi siswa?
Yulnawati : "Biase e kalau dikelas ade siswa yang inklusi sering begendang pakai meja. Tapi saya ngebiar e asal dak mengganggu kawan lain. Kadang pas jam pelajaran lah kek selesai saya sengaja membiarkan siswa melakukan apa yang mereka inginkan. Misal e begendang, nyanyi- nyanyi, maen kek kawan-kawan e. Soal e men dak macam ya siswa sering bosan." 24

Berdasarkan hasil wawancara, observasi dan juga dokumentasi, guru PAI secara sederhana telah melaksanakan kegiatan untuk mengembangkan kecerdasan kinestetik bagi siswanya, yakni dengan memberikan kebebasan bagi siswanya untuk mengekspresikan atau melakukan apa yang mereka inginkan asalkan tidak mengganggu teman lainnya.

\section{f. Kegiatan Dalam Mengembangkan Kecerdasan Musikal}

Kegiatan yang dilakukan oleh guru PAI dalam mengembangkan kecerdasan musikal siswa sering peneliti amati ketika proses pembelajaran berlangsung, biasanya guru PAI mengajak siswa untuk sholawatan, dan kadang membaca surat-surat pendek dengan menggunakan irama (tilawah). Terkadang pada saat pelajaran berlangsung guru PAI juga memperdengarkan lagu-lagu yang berkaitan dengan materi. Hal tersebut juga diperkuat dengan pernyataan guru PAI dalam wawancara yakni:

Peneliti : "kegiatan apa saja yang dilakukan dalam mengembangkan kecerdasan musikal bagi siswa?

Yulnawati : "Biase e ade materi yang disampaikan dengan musik. Seperti mengaji dengan irama, sholawatan.Dengan mendengarkan lagu-lagu yang berkaitan dengan materi yang disampaikan."25

\footnotetext{
${ }^{24}$ Wawancara dengan Yulnawati, Guru PAI SMP Negeri 3 Sungailiat,tanggal 18 Juli 2018 di Ruang Tunggu Tamu SMP Negeri 3 Sungailiat.

${ }^{25}$ Wawancara dengan Yulnawati, Guru PAI SMP Negeri 3 Sungailiat,tanggal 18 Juli 2018 di Ruang Tunggu Tamu SMP Negeri 3 Sungailiat.
} 
Berdasarkan hasil observasi dan wawancara yang peneliti dapatkan, guru PAI telah melaksanakan kegiatan untuk mengembangkan kecerdasan musikal siswa yakni dengan mengajak siswa sholawatan, memutarkan musik yang berkaitan dengan materi pada saat jam pelajaran.

g. Kegiatan Dalam Mengembangkan Kecerdasan Interpersonal

Guru PAI telah banyak mengupayakan untuk mengembangkan kecerdasan interpersonal siswa, kegiatan yang dilakukan, berdasarkan hasil wawancara dengan guru PAI adalah dengan berdiskusi, belajar kelompok, dan terkadang siswa yang telah paham pelajaran diminta mengajari teman yang belum paham materi pelajaran.

Hal serupa juga diugkapkan oleh beberapa siswa berikut ini:

Peneliti : "apakah guru PAI pernah mengajak untuk berdiskusi kelompok?

Anggi : "Pernah, Biase e kami diskusi kelompok kalo ade materi yang lom kami paham." 26

Peneliti : "apakah guru PAI pernah meminta mengajari teman yang belum paham materi pelajaran?

Selia : "Pernah, malah sering. misalnya materi tentang asmaul husna biase e pas lah selesai jam pelajaran di sekolah." 27

Berdasarkan hasil wawancara, observasi dan dokumentasi yang telah peneliti peroleh, guru PAI telah melaksanakan kegiatan yang bertujuan mengembangkan kecerdasan interpersonal siswa, yakni dengan diskusi, belajar kelompok, dan meminta siswa yang telah paham materi pelajaran utnuk mengajari temannya yang belum paham.

Hal tersebut sesuai dengan yang telah disebutkan oleh Thomas Amstrong bahwa belajar melaluicara interpersonal merupakan belajar dengan memberikan kesempatan untuk mengajari teman-teman lain serta menyediakan berbagai permainan yang bisa dilakukan bersama. Kegiatan diskusi dan belajar kelompok yang dilakukan juga menguatkan apa yang disampaikan oleh Muhammad Yaumi bahwa untuk mengembangkan kecerdasan interpersonal yang dimiliki oleh siswa dengan melaksanakan berbagai kegiatan pembelajaran yang sesuai seperti dengan melaluimetode jigsaw,

\footnotetext{
${ }^{26}$ Wawancara dengan Anggi Meilinda, Siswa Kelas ix A,tanggal 27 Juli 2018 di SMP Negeri 3 Sungailiat.

${ }^{27}$ Wawancara dengan Selia Septiani Lestari, Siswa Kelas ix B,tanggal 27 Juli 2018 di SMP Negeri 3 Sungailiat.
} 
mengajar teman sebaya, bekerja tim, diskusi kelompok, membuat dan melakukan wawancara, dan menebak karakter orang lain.

h. Kegiatan Dalam Mengembangkan Kecerdasan Intrapersonal

Kegiatan yang dilakukan guru PAI dalam mengembangkan kecerdasan intrapersonal dalam pembelajaran sebagaimana yang disampaikan guru PAI dalam wawancara sebagai berikut:

Peneliti :" apa saja kegiatan yang dilakukan dalam mengembangkan kecerdasan intrapersonal bagi siswa?"

Yulnawati :" Saya pernah menyuruh siswa menulis tentang diri mereka sendiri, dan juga tentang pesan dan kesan mereka selama belajar." 28

Hasil wawancara dengan guru PAI tersebut diperkuat dengan pernyataan beberapa siswa berikut ini:

Peneliti : " pernahkah kamu diminta guru PAI untuk menuliskan tentang diri sendiri?"

Anggi : "Pernah, pada saat pertemuan pertama dan di akhir semester, biase e saya menulis tentang kesan selama belajar bersama guru PAI."29

Peneliti : "apakah setiap selesai pembelajaran guru PAI memberikan tugas?"

Suchi : "Iya. Sering"30

Peneliti : "apakah guru PAI mengajarimu jika kamu belum paham terhadap materi pelajaran tertentu?kalu iya bagaimana cara guru PAI mengajarinya?"

Anggi : " Iya, dengan cara menjelaskan kembali secara rinci, dan terkadang dengan metode yang lain." 31

Berdasarkan hasil wawancara, guru PAI telah melaksanakan kegiatan tersebut yakni dengan meminta siswa untuk menuliskan tentang diri sendiri serta dengan memberikan tugas secara individu setelah pelajaran selesai. Kegiatan ini masih bercampur dengan pengembangkan kecerdasan lainnya, sehingga kegiatan khusus untuk mengembangkan kecerdasan intrapersonal ini masih belum begitu terlihat.

\footnotetext{
${ }^{28}$ Wawancara dengan Yulnawati, Guru PAI SMP Negeri 3 Sungailiat,tanggal 18 Juli 2018 di Ruang Tunggu Tamu SMP Negeri 3 Sungailiat.

${ }^{29}$ Wawancara dengan Suchi Melinda, Siswa Kelas ix A,tanggal 27 Juli 2018 di SMP Negeri 3 Sungailiat.

${ }^{30}$ Wawancara dengan Anggi Meilinda, Siswa Kelas ix A,tanggal 27 Juli 2018 di SMP Negeri 3 Sungailiat.

${ }^{31}$ Wawancara dengan Anggi Meilinda, Siswa Kelas ix A,tanggal 27 Juli 2018 di SMP Negeri 3 Sungailiat.
} 
Hal ini sesuai dengan yang dinyatakan oleh Linda Campbell, dkk bahwa kegiatan yang dapat dilakukan untuk mengembangkan kecerdasan intrapersonal antara lain adalah dengan membuat situasi dimana siswa mampu mengakui kekurangan dan kelebihan yang dimiliki masing-masing. Kegiatan ini masih bercampur dengan pengembangkan kecerdasan lainnya, sehingga kegiatan khusus untuk mengembangkan kecerdasan intrapersonal ini masih belum begitu terlihat.

i. Kegiatan Dalam Mengembangkan Kecerdasan Naturalis

Kegiatan untuk mengembangkan kecerdasan ini yang dilakukan guru PAI pernah peneliti amati ketika melakukan observasi yakni guru PAI mengajak siswanya untuk belajar di luar kelas. hal inipun berdasarkan hasil wawancara peneliti dengan guru PAI bahwa kegiatan yang dilakukan adalah siswa diminta untuk mengamati tumbuh-tumbuhan yang ada dilingkungan sekolah, terkadang juga kegiatan itu dilakukan pada saat kebersihan sekolah.

Hal tersebut di atas juga diperkuat dengan pernyataan siswa pada saat wawancara sebagai berikut:

Peneliti : "apakah guru PAI pernah mengajak untuk belajar di luar kelas?"

Anggi : "Pernah, kadang waktu e sambil kebersihan halaman sekolah." 32

Peneliti : "apakah kamu pernah diminta untuk mengamati tumbuhan atau hewan?"

Marcello: "Pernah kalo tumbuhan, pas keluar kelas kami disuruh mengamati pohon-pohon"33

Berdasarkan hasil wawancara, observasi, dan dokumentasi, secara sederhana guru PAI telah melaksanakan kegiatan untuk mengembangkan kecerdasan naturalis bagi siswa yakni dengan melakukan pengamatan terhadap tumbuh-tumbuhan di lingkungan sekolah.

j. Kegiatan Dalam Mengembangkan Kecerdasan Eksistensialis

Kecerdasan eksistensialis sering berkaitan dengan kecerdasan spiritual, di mana seperti yang peneliti amati di SMP Negeri 3 Sungailiat, dalam mengembangkan kecerdasan eksistensialis guru PAI selalu meminta siswa berdoa sebelum dan sesudah belajar. Berdasarkan observasi peneliti, pada saat pelajaran berlangsung dikelas terlihat guru PAI menjelaskan materi pelajaran dengan mengaitkannya dengan ayat-ayat Al-Quran.

\footnotetext{
${ }^{32}$ Wawancara dengan Anggi Meilinda, Siswa Kelas ix A,tanggal 27 Juli 2018 di SMP Negeri 3 Sungailiat.

${ }^{33}$ Wawancara dengan Marcello, Siswa Kelas ix E,tanggal 27 Juli 2018 di SMP Negeri 3 Sungailiat.
} 
Hal ini juga diperkuat dengan penyataan guru PAI dalam wawancara yang dilakukan peneliti berikut ini:

Peneliti : “ apa saja kegiatan yang dilakukan dalam mengembangkan kecerdasan eksistensialis siswa?"

Yulnawati: "Kegiatan yang biase e dilakukan tu lebih berkaitan dengan spiritual,kegiatan e tu sering pada saat jam pelajaran contohnya berdoa sebelum dan sesudah belajar, kadang materi yang disampaikan dikaitkan dengan ayat-ayat al-Quran, pernah siswa di nasehati dengan contoh teladan dari cerita nabi dan sahabat."34

Berdasarkan hasil observasi dan wawancara yang peneliti dapatkan, bahwa guru PAI telah melakukan kegiatan untuk mengembangkan kecerdasan eksistensialis siswa yakni dengan membiasakan siswa untuk berdoa sebelum dan sesudah belajar, kegiatan ini terlihat oleh peneliti dilakukan setiap hari selama proses penelitian.

Namun hal ini tidak sependapat dengan yang dikatakan oleh Muhammad Yaumi bahwa dalam mengembangkan kecerdasan Eksistensialis dapat dilakukan dengan membuat respon tentang sesuatu, dan berdiskusi dengan isu-isu sosial.

Dalam proses pembelajaran PAI, guru PAI di SMP Negeri 3 Sungailiat lebih memfokuskan mengembangkan kecerdasan siswa sesuai dengan materi yang diajarkan, dan dari sembilan jenis kecerdasan, hanya 5 (lima) kecerdasan yang lebih ditekan guru PAI untuk dilaksanakan yakni kecerdasan Linguistik-verbal, kecerdasan visual-spasial, kecerdasan kinestetik, kecerdasan musikal, dan kecerdasan eksistensialis, dengan kegiatan dan metode yang dilakukan seperti dijelaskan sebelumnya.

\section{Problematika Dalam Penerapan Strategi Multiple Intelligences}

Penerapan strategi multiple intelligences di SMP Negeri 3 Sungailiat terdapat hambatan yang dihadapi sekolah dan guru yakni hambatan yang terjadi pada persiapan pembelajaran, pelaksanaan pembelajaran dan pada penilaian pembelajaran.

a. Hambatan dalam Persiapan Pembelajaran

Guru PAI dan juga kepala sekolah mengakui bahwa terdapat hambatan dalam persiapan pembelajaran yakni hambatan yang terjadi pada pelaksanaan kegiatan untuk mengenali kecerdasan masing-masing siswa.

\footnotetext{
${ }^{34}$ Wawancara dengan Yulnawati, Guru PAI SMP Negeri 3 Sungailiat,tanggal 18 Juli 2018 di Ruang Tunggu Tamu SMP Negeri 3 Sungailiat.
} 
Dapat disimpulkan bahwa Terdapat 5 hambatan di dalam mempersiapkan pembelajaran dengan menggunakan strategi multiple intelligences di SMP Negeri 3 Sungailiat yakni:

1) Sekolah umumnya dan guru khususnya belum siap untuk melaksanakan tes secara khusus untuk mengenali kecerdasan masing-masing siswa.

2) Penyusunan rencana pembelajaran yang tidak maksimal

3) Guru masih meragukan kemampuannya dalam melaksanakan pembelajaran berdasarkan rencana pembelajaran.

4) Guru masih kesulitan mengaitkan materi pelajaran dengan kehidupan sehari-hari.

5) Guru yang kurang kreatif dalam menggunakan metode pembelajaran.

b. Hambatan dalam Pelaksanaan Pembelajaran

Berdasarkan hasil wawancara dengan guru PAI, Pada tahap pelaksanaan pembelajaran dengan menggunakan strategi multipleintelligences, bahwa guru masih kesulitan dalam mengembangkan kesembilan jenis kecerdasan tersebut, berdasarkan observasi peneliti hal tersebut disebabkan guru kurang menguasai metode yang digunakan dalam mengajar dan juga tidak didukung oleh peralatan atau media yang memadai.

Semestinya dalam mengembangkan kecerdasan siswa dengan strategi Multiple Intelligences tidaklah sulit, Yang dibutuhkan hanyalah guru yang kreatif dan peka, artinya guru harus berpikir terbuka dan tidak mengajar secara tradisional dan menggunakan sarana prasana yang telah tersedia di lingkungan sekitar.

Hal tersebut di atas bertentangan dengan yang dinyatakan oleh Vernon A. Magnesen bahwa seseorang belajar setidaknya 10\% dari apa yang kita baca, 20\% dari apa yang kita dengar, 30\% dari apa yang kita lihat, 50\% dari apa yang kita lihat dan dengar, $70 \%$ dari apa yang kita katakan, 90\% dari apa yang kita katakan dan lakukan. Hal tersebut berarti bahwa seseorang bisa menyerap informasi atau belajar paling banyak pada saat orang tersebut melakukan atau mempraktekkan materi yang diterimanya.

c. Hambatan dalam Penilaian Pembelajaran

Pada tahap ini, guru sering mengalami kendala pada setiap aspek penilaian, yakni kognitif, afektif dan psikomotorik.Berdasarkan observasi peneliti guru berusaha keras dalam mengatasi siswa yang tidak tercapai KKM dapat mencapai KKM tersebut sesuai dengan kemampuannya.Guru juga kesulitan mengajak siswa belajar lebih giat ketika hal 
tersebut bukan pada bidang yang siswa sukai. Hal tersebut juga dinyatakan guru PAI pada saat wawancara sebagai berikut:

Peneliti : "Apa hambatan atau kendala dalam penilaian pembelajaran dengan menggunakan strategi multiple intelligences pada mata pelajaran PAI? “

Yulnawati: "saya agak kesulitan memberikan penilaian afektif siswa karena untuk menilai afektif dak bisa dilakukan pada saat itu juga, melainkan dengan cara bertahap. Kalo utk kognitif contohnya Kadang ade anak yang tidak bisa mengaji sulit memberikan nilai untuk mengimbangi siswa yang sudah baik, men penilaian psikomotoriknya siswa ni susah di atur kalo dak sesuai kek bidang yang di sukai”

Dari uraian diatas dapat disimpulkan bahwa pada saat penilaian guru mengalami hambatan pada setiap aspek penilaian yakni pertama aspek kognitif, yakni bahwa guru kesulitan dalam mengatasi siswa yang tidak dapat mencapai KKM, sehingga guru dituntut untuk berusaha keras agar siswa yang tidak dapat mencapai KKM bisa mencapai KKM tersebut sesuai kemampuannya. Kedua aspek afektif, hambatannya adalah guru dituntut memberikan nilai afektif siswa dalam waktu yang singkat, sedangkan untuk penilaian aspek afektif guru tidak bisa menilai pada saat itu juga, namun harus bertahap.Ketiga hambatan dalam penilaian aspek psikomotorik, adalah siswa sulit diajak belajar secara maksimal jika materinya bukan bidang yang disukai.

3. Prestasi Belajar Siswa Pada Pelajaran Pai

Hasil belajar siswa yang juga berdampak pada prestasi siswa akan dipengaruhi oleh proses pembelajaran, dan juga merupakan hasil dari proses penilaian yang dilakukan oleh guru dalam pembelajaran. Adapun penilaian yang digunakan guru PAI merupakan bentuk penilaian autentik. Berikut deskripsi dari masing-masing aspek penilaian:

a. Penilaian Aspek Kognitif

Berdasarkan wawancara peneliti dengan guru PAI, alat penilaian kognitif yang digunakan guru PAI untuk menilai siswa adalah dengan menggunakan tes tertulis, tes lisan dan memberikan tugas baik tugas individu maupun tugas kelompok.Adapun tes lisan dilakukan secara spontan oleh guru PAI.

Pada saat peneliti melakukan observasi, peneliti melihat guru PAI melakukan tes lisan dengan memberikan pertanyaan tentang Tanda-Tanda Hari Akhir, bagi siswa yang bisa menjawab akan diberikan nilai. Berdasarkan observasi, guru PAI pernah beberapa 
kali melakukan tes tertulis dan juga tes lisan, tetapi sangat disayangkan guru PAI tidak memasukkan sebagian tes tersebut sebagai nilai, hal tersebut hanya bertujuan untuk memberikan pemahaman kepada siswa.

b. Penilaian Aspek Afektif

Penilaian terhadap sikap siswa dilakukan guru PAI murni dengan pengamatan langsung terhadap masing-masing siswa, yakni bagaimana siswa berinteraksi dengan guru, dan interaksi dengan sesama teman yang beragama sama maupun yang berbeda agama di dalam kelas maupun di luar kelas.

c. Penilaian Aspek Psikomotorik

Penilaian psikomotorik yang dilakukan oleh guru PAI terhadap siswa yakni dengan praktek. Hal tersebut berdasarkan hasil observasi pada saat pembelajaran guru memberikan tugas hafalan yang akan disetor hafalannya pada pertemuan berikutnya. Penilaian tidak hanya terletak pada ayat-ayat yang dihafalkan, tetapi juga keterampilan dalam melakukan bacaan Al-Qur'an dengan ketepatan bacaan, yang berarti penggunaan tajwid dan fashohah harus benar.

Hasil belajar siswa yang akan berdampak pada prestasi siswa dipengaruhi oleh proses pembelajaran, yang merupakan hasil dari proses penilaian yang dilakukan oleh guru dalam pembelajaran. Penilaian pada ketiga aspek penilaian yakni kognitif, afektif dan psikomotorik, strategi penilaian dilakukan melalui tiga tahapan yakni:

a. Strategi Tahap I

Pada tahap I, materi pokok yang menjadi pembahasan adalah Surat At-Tiin dengan 2 kali pertemuan dengan setiap pertemuan dilakukan selama 80 menit.Berdasarkan hasil observasi secara umum pada tahap 1 dapat dikatakan belum berhasil, hal tersebut disebabkan oleh beberapa permasalahan antara lain:

1) Siswa tidak fokus mengikuti pembelajaran, hal itu disebabkan karena metode yang digunakan guru belum mampu mengontrol suasana keramaian yang ditimbulkan siswa.

2) Siswa belum menikmati belajar dengan metode baru sehingga siswa tidak berani

b. Strategi Tahap II

Pada tahap II, guru melakukan perbaikan terhadap permasalahan, kekurangan serta hambatan yang terjadi pada tahap I, sehingga diharapkan pada tahap II akan mendapatkan hasil yang lebih baik. Secara umum pada tahap II ini sudah dapat dikatakan 
lebih baik dari pada tahap I, walaupun masih terdapat kondisi yang belum maksimal, hal tersebut akan dilakukan perbaikan pada tahap III.

Adapun gambaran kondisi guru dan siswa dalam tahap II adalah:

1) Siswa mulai menikmati serta dapat mengikuti pembelajaran dengan baik.

2) Siswa mulai menunjukkan keaktifan.

3) Terjadi perkembangan Kondisi kognitif, afektif dan psikomotorik siswa.

4) Guru mulai terbiasa dan lebih enjoi dalam menggunakan metode dan media pembelajaran, serta mulai mampu mengkondisikan siswa.

c. Strategi Tahap III

Pada tahap III ini, guru menggunakan metode pembelajaran yang berbeda dengan tahap sebelumnya yang hanya menggunakan metode ceramah, cerita pengalaman dan diskusi.Pada tahap III ini guru menambahkan dengan menggunakan metode gambar, permainan, dan juga analisis hikmah.

Adapun gambaran tentang kondisi siswa dan guru pada tahap III ini adalah sebagai berikut:

1) Siswa telah menikmati serta mengikuti pembelajaran dengan baik.

2) Siswa menunjukkan keaktifannya, dengan mengangkatkan tangan untuk memberikan pertanyaan dan bahkan bisa memberikan jawaban dengan baik ketika guru memberikan pertanyaan.

3) Terjadi perkembangan dalam Kondisi kognitif, afektif dan psikomotorik siswa.

4) Guru telah menguasai materi dan punya kepercaaan diri sehingga mampu menggunakan metode dan media pembelajaran dengan baik.

\section{E. KESIMPULAN}

Penerapan Strategi Multiple Intelligences Pada Mata Pelajaran Pendidikan Agama Islam Di SMP Negeri 3 Sungailiat dilaksanakan melalui tahap persiapan pembelajaran dan pelaksanaan pembelajaran. Adapun Persiapan pembelajaran di SMP Negeri 3 Sungailiat yakni dengan mengenali kecerdasan siswa dan membuat rencana pembelajaran, sedangkan pelaksanaan pembelajaran dengan menggunakan strategi multiple intelligences di SMP Negeri 3 Sungailiat yakni dengan melakukan kegiatan apersepsi dan motivasi dan melaksanakan kegiatan berdasarkan kecerdasan yang akan dikembangkan. Penerapan strategi Multiple Intelligences dilaksanakan dengan caramenggunakan metode yang 
disesuaikan dengan jenis kecerdasan siswa, diantara metode pembelajaran yang digunakan adalah metode praktik, permainan, tanya jawab, diskusi, analisis hikmah, cerita pengalaman, dan membaca.

Problematika dalam penerapan strategi Multiple Intelligences di SMP Negeri 3 Sungailiat terdapat pada saat persiapan pembelajaran, pelaksanaan pembelajaran, dan juga pada saat penilaian. Adapun problem yang terjadi antara lain: SMP Negeri 3 Sungailiat belum siap secara maksimal, guru yang menggunakan Multiple intelligences belum kreatif sehingga kesulitan dalam menggali berbagai macam strategi yang dapat digunakan untuk mengembangkan kecerdasan setiap siswa, dan masih minimnya sarana prasarana pendidikan. Guru juga belum mampu memahami dan mengekplorasikan kecerdasan siswa yang sangat variatif, terutama dalam mengembangan kecerdasan siswa sesuai dengan materi dalam pelajaran PAI.

Prestasi siswa SMP Negeri 3 Sungailiat meningkat lebih baik, karena menggunakan strategi Multiple Intelligences dalam pelaksanaan belajar mengajar. Prestasi tersebut ditunjukkan dengan siswa belajar lebih aktif, munculnya potensi yang dimiliki siswa, siswa memiliki keberanian serta siswa memiliki kebebasan untuk memilih cara belajar yang membuat mereka senang dan nyaman, sehingga hasil belajar (prestasi) mereka pada mata PAI pun meningkat. 


\section{DAFTAR PUSTAKA}

Abdullah, Abdurrahman Saleh. (1994). Teori-teori Pendidikan berdasarkan Al-Qur'an, cet. Kedua. Jakarta: Rineka Cipta.

Al Abrasyi, Muhammad Athiyah. Al- Tarbiyah al Islamiyah, Cet. 3, Dar al Fikr al Arabi, tt.

Azra, Azyumardi. (2012). Pendidikan Islam Tradisi dan Modernisasi di Tengah Tantangan Milenium Ill. Jakarta: Prenada Madia Group

C.P. Chaplin. (1993) Kamus Lengkap Psikologi. Jakarta: PT. Raja Grafindo Persada.

Chatib, Munif. (2009). Sekolahnya Manusia. Bandung: Kaifa

Chatib, Munif. (2016). Gurunya Manusia. Bandung :Kaifa

Darajat, Zakiah. (2001). Dasar-Dasar Agama Islam. Jakarta: Bulan Bintang

DePorter. (2000). Quantum Teaching; Mempraktikkan Quantum Learning Di Ruang-Ruang Kelas. Bandung:PT. Mizan Pustaka

Djamarah, Syaiful Bahri. (2000). Guru Dan Anak Didik Dalam Interaksi Edukatif. Jakarta: Rineka Cipta

Ensiklopedi Nasional Indonesia, (1998) Jakarta: PT. Cipta Adi Pustaka

Hamzah B. dan Masri Kuadrat. (2009) Mengelola Kecerdasan dalam Pembelajaran: Sebuah Konsep Pembelajaran Berbasis Kecerdasan. Jakarta: Bumi Aksara

Harahap, Soegarda Poerbakawatja. (1982). EnsiklopediPendidikan. Jakarta: PT.Gunung Agung.

Hasbullah (2015). Dasar-dasar Ilmu Pendidikan, Revisi Cet. 12. Jakarta : Rajawali Pers.

Majid, Abdul M. (2012). Belajar dan Pembelajaran Pendidikan Agama Islam. Bandung: PT. Remaja Rosdakarya.

Muzakki, Akh \& Kholilah. (2011). Ilmu Pendidikan Agama Islam, Cet. 5, Surabaya: Mesmedia Buana Pustaka.

Ramayulis. (2001). Metodologi Pengajaran Agama Islam, cet ketiga. Jakarta: Kalam Mulia. 
Remiswal dan Rezki Amelia. (2013). Format Pengembangan Strategi PAIKEM Dalam Pembelajaran Pendidikan Agama Islam. UIN Maulana Malik Ibrahin Malang.

Tafsir, Ahmad. (2001). Ilmu Pendidikan Dalam Persfektif Islam. Bandung: Remaja Rosda Karya

Usman, Moh Uzer. (1992). Menjadi Guru Profesional. Bandung: Remaja Rosdakarya 